\section{Charles M. Hardin}

Charles M. Hardin, a political scientist ahead of his time, or at least a different intellectual time zone from most of his colleagues, died June 28 1997, at his daughter's home in San Francisco. Starting out as a specialist in the politics of agriculture, Hardin broadened out not only as a leading constitutional scholar but as a critic who found the Constitution undemocratic and outdated.

Charles Hardin's point of attack was the separation of power, which he believed led to fragmentation of authority and deadlock of action. $\mathrm{He}$ argued for replacing the separation of powers between the executive and the legislature with a separation between the government and the opposition. This would call for a stronger party in power and a stronger party in opposition. Thus, he believed in party reorganization as well as constitutional reform. At the same time, he was concerned about excessive presidential power and unaccountability. These views were reflected in two notable volumes: Presidential Power \& Accountability: Toward a New Constitution (1974) and Constitutional Reform in America (1989).

In 1981, carrying these concerns into the public arena, Hardin joined C. Douglas Dillon, Secretary of the Treasury under President Kennedy, Senator Nancy Kassebaum, and former presidential counsel Lloyd Cutler, along with lawyers and scholars of political science and other disciplines, in founding the Committee on the Constitutional System, a group dedicated to analyzing the strengths and weaknesses of that system. He took part in discussions leading to CCS proposals that the president, senators, and representatives be elected jointly every four years, that a power of dissolution be established that would enable the President and Congress to avoid or overcome deadlock, and that the President be empowered to appoint members of Congress to serve in his cabinet without losing their legislative seats. Hardin's only criticism of the CCS recommendations was that they did not go far enough.

Earlier, in the 1970s, Hardin had urged not only constitutional reform but party reorganization and re- newal. The best way to make the President responsible, he held, was through a vigorous party opposition. By the same token he derided the popular belief in consensus and bipartisanship. Party government, he insisted, would give citizens their due share of both political power and responsibility. The idea of presidential leadership and party government he concluded, "raise the most important secular questions of our time."

Charles Hardin was as easy and forthcoming in manner as he was vigorous in thought. At the University of California, Davis, where he taught many years, he is remembered by colleagues and former students for his kindly ways and spirit. $\mathrm{He}$ is survived by his wife, the former Sallie Gibson, a daughter, Julia Hardin Hansen, two grandchildren, and a great grandson.

\section{Thor Swanson}

\section{Fred Warner Neal}

Fred Warner Neal, emeritus professor of political science at The Claremont Graduate School, died on November 21, 1996, as a result of injuries he received from being struck by a car.

A nationally renowned expert in the affairs of Russia and the republics of the former Soviet Union and of the Balkans and the republics of the former Yugoslavia, Fred Neal joined the faculty of The Claremont Graduate School in 1957, where he served with distinction until his death. He founded the School's Program in International Relations and served as its chair for many years. $\mathrm{He}$ retired from active teaching and was named emeritus professor in 1983.

Born in Northville, Michigan, in 1915, Neal earned his Bachelor's degree from the University of Michigan in 1938. He received his Ph.D. from Michigan in 1955. He also studied at Harvard University as a Niemann Fellow and the Sorbonne in Paris as a Fullbright research fellow.

Neal's interest in Russian affairs can be traced back to his service as a Naval Air Corps Lieutenant in Russia and Siberia from 1943 to 1946. After the war, Neal spent three years as a consultant on Russian affairs to the U.S. Department of State and as chief of foreign research on Eastern Europe.

After beginning his professional career as a Washington and foreign correspondent for the Wall Street Journal, Neal joined the faculty of the University of Colorado in 1951, and taught at the University of California, Los Angeles, before moving to The Claremont Graduate School. He received many awards during his long career, including fellowships from the Rockefeller Foundation, the Social Science Research Council, and American Philosophical Society. In 1990, Neal became the first American to receive Yugoslavia's highest civilian honor, the Order of the Yugoslav Flag with Golden Wreath.

Author of numerous books and articles on the Soviet Union and international relations, Neal's most notable publications include Detente or Debacle: Common Sense in U.S.Soviet Relations (1979); A Survey of Detente-Past, Present, Future (1977); and Yugoslavia and the New Communism (1962). Neal also found time to serve as organizer and director of four Pacem Terris Convocations of the Center for Study of Democratic Institutions, founder and executive vice president of the American Committee on East-West Accord, and chairman of the Executive Committee on U.S.-Soviet Relations.

A lifelong proponent of peaceful coexistence and a fervent opponent of the Cold War, Neal summed up his personal professional philosophy in his Who's Who entry: "I have become convinced of the essential similarity in human motivations and, also, the essential differences in their expression imposed by different cultures; of the oneness of nature; of the unlikeness and, usually, the undesirability of extreme solutions; of the difficulties of one generation imparting values to another; of the honor of patriotism and its moral dangers; and of the incomprehensibility of life as well as the joy of engaging in the struggle to comprehend it."

To honor Neal's memory and to carry forward his legacy, his family and the Claremont school administration have established the Fred Warner Neal Lecture Fund. Contributions may be made to The Clar- 
emont Graduate School, Office of the President, 160 East 10th Street, Claremont, CA 91711.

Adapted from The Claremont Graduate School News

\section{Gerhart Niemeyer}

Gerhart Niemeyer, emeritus professor of government and international studies at the University of Notre Dame passed away June 23, 1997.

Niemeyer was born in Essen, Germany, on February 15, 1907. He studied political science at Cambridge and the German Universities of Munich and Kiel. He received a law degree from the University of Kiel in 1932 before leaving Germany during the early years of Hitler's regime. He lived for a time in Spain before emigrating to the United States, where he joined the faculty of Princeton University in 1937. In 1941 he published a widely praised book, Law Without Force, which rapidly became required reading for students of international law.

The U.S. State Department appointed Niemeyer to the planning staff of its Bureau of United Nations Affairs in 1950, and after three years in that post, he became an analyst for the Council on Foreign Relations. He joined the Notre Dame faculty in 1955 .

At Notre Dame, Niemeyer taught introductory courses on political theory as well as two popular courses, "Modern Political Ideologies," and "The Reconstruction of Political Theory." He also wrote numerous articles in scholarly and popular journals on a variety of topics including cultural history, the New Left, education, and the writings of Eric Voeglin and Alexander Solzhenitsyn. In 1972, when the editor of Notre Dame Magazine invited several faculty members to write their own epitaphs, Niemeyer's cryptic submission read, "Brief span the Gift, Cool bed the dot. Struggle for the lot. Look for the Lift."

Michael O. Garvy

University of Notre Dame

\section{Sam Nolutshungu}

Sam C. Nolutshungu, professor of political science and African politics at the University of Rochester, died of cancer on August 12, 1997.

Professor Nolutshungu was an internationally acclaimed expert on South African politics. "He was a world-class scholar, a gifted teacher, and a vital intellectual force in the department, the College, and the broader intellectual community," said Harold W. Stanley, chair of the University's department of political science. "He combined these considerable talents with great warmth, grace, and kindness."

In December 1996, Nolutshungu was selected to be the next vice chancellor at the University of the Witwatersrand in Johannesburg, South Africa, considered one of the most powerful and prestigious academic positions in that country. But in January he declined the post for health reasons.

As a university student, Sam Nolutshungu left his homeland because of apartheid policies and went into exile in England, where he stayed to earn his doctorate and become a university faculty member. In a newspaper article last year, he told a reporter: "There is a great sense of satisfaction in seeing the ideas we espoused then becoming the foundation for the new South Africa."

Before his arrival in Rochester, Nolutshungu served on the faculty of the University of Manchester where he was Tutor to the Honours School of Politics and Modern History. He also held positions on the faculties of the University of Lancaster, the University of Ibadan, York University in Toronto, and Dartmouth College, and he was a visiting research fellow at Yale University.

Nolutshungu came to the University of Rochester in 1991 as a tenured professor in the political science department. He also held a joint appointment in the University's Frederick Douglass Institute for Af- rican and African-American Studies and served as the Institute's acting director from 1995 to 1997.

In his academic career, Professor Nolutshungu had specialized in international politics with an emphasis on the politics of South Africa. He had written five books and numerous articles on Africa. His doctoral thesis at the University of Manchester published in 1975 South Africa in Africa: A Study of Ideology and Foreign Policy, is considered to be the first major study of South African politics by a black South African.

Earlier this year, Nolutshungu told colleagues that he decided to apply for the top administrative position at Witwatersrand "because I saw in it a brilliant opportunity to render service to my country. I believed that my experience of university education in different countries and continents would be of value to Witwatersrand and South Africa. I was convinced that the academic work I had pursued for a quarter of a century into the problems of South Africa and the African continent would reinforce that contribution."

Professor Nolutshungu was an active member of the international political science community as reflected in his membership on the Social Science Research Council Committee on International Peace and Security. In recent years, his research and teaching focused on the transformation of the apartheid state in South Africa. In particular, he was exploring the relationships between democratized politics, a constitutional commitment to non-racism, and reforms to reduce racialized economic inequality.

He is survived by his wife Veli and two daughters, Nomvuyo and Nomalungelo and a brother, Peter.

\section{Sharon Dickman}

University of Rochester 